\title{
A study on habitats and behavioral characteristics of hornet wasp (Hymenoptera: Vespidae: Vespa orientalis), an important medical-health pest.
}

\author{
Dehghani $\mathbf{R}^{1}$, Kassiri $\mathbf{H}^{2 *}$, Mazaheri-Tehrani $\mathrm{A}^{\mathbf{3}}$, Hesam $\mathbf{M}^{\mathbf{3}}$, Valazadi $\mathbf{N}^{\mathbf{1}}$, Mohammadzadeh $\mathbf{M}^{1}$ \\ ${ }^{1}$ Social Determinants of Health Research Center and Department of Environment Health, Kashan University of Medical \\ Sciences, Kashan, Iran \\ ${ }^{2}$ Department of Medical Entomology, Health School, Ahvaz Jundishapur University of Medical Sciences, Ahvaz, Iran \\ ${ }^{3}$ Department of Environment Health Engineering, Hamadan University of Medical Sciences, Hamadan, Iran
}

\begin{abstract}
Hornet wasp or Vespa orietalis is one of the social and stinging insects of Iran that makes its nest mostly in the holes and cracks in the ground. Given the point that no study has been conducted in this case, yet, in this study, the nests of this arthropod are studied in four mountainous and plain areas in Kashan. Present study was of descriptive type and during it four nests of $V$. orientalis in four agricultural, residential, administrative and mountainous regions were identified and studied. The identification of the nests of these animals was done on the basis of observation abundance of this wasp around the nests, defense and the existence of definite tumulus in farmlands from May to September 2016-2-17. Tumulus, the nest of $V$. orientalis was irregular in farmland and imperceptible in residential and mountainous regions. The entrance of the nests in the soil was $3 \times 5 \mathrm{~cm}$. The nests of this hunter wasp were in the regions where a large number of its feeding arthropods were active. This study showed that the red wasps feed on cockroaches in residential regions, Schirasi woodlouse (Hemilepistus schirasi) and the larvae of butterflies in agricultural lands, and honey bees, larvae of butterflies and other insects in other regions. The results of this study revealed that the nests of $V$. orientalis as an opportunistic arthropod are seen in different places and if needed, this animal cleans the nests and to some extent it is a builder, occupier or tenant of the nest. The existence of this animal that nests in human habitats causes danger especially for children.
\end{abstract}

Keywords: Hornet wasp, Ecology, Behaviour, Vespa orientalis.

Accepted on December 28, 2018

\section{Introduction}

Since the creation, humans have been in contact with different animals on the earth. Due to incorrect or false belief, some of these animals have caused fear and discomfort in humans. Fear of animals is different at different age and gender groups. Fear caused by animals is not always due to awareness but it may be because of the shape, type of behavior and their disgusting features and contact with human skin. Fear of animals due to the probable damages caused by them is correct but in some cases, it has been mingled with superstition and false ideas [1]. And some other animals have caused infection, poisoning and diseases in humans by biting and stinging. Humans have always been exposed to biting by different poisonous and nonpoisonous animals [2,3].

Iran has the most diverse plant and animal species due to high climatic diversity. Poisonous biting and stinging animals from distant pasts have been noticed more than others. Stinging and biting by scorpions and snakes has always been raised as one of the medical and treatment problems in Iran. Given the high diversity of scorpion and snake species in the vast expanse of Iran that live in the southern islands of Persian Gulf to the northern regions [4-6]. Cases of biting by these reptile animals or arthropods are reported [7-11]. Among aquatic animals some such as back swimmer cause painful bites if they feel danger. Their bite like that of wasp is painful and the pain continues for 2-3 h $[12,13]$. Scorpions are considered among the most major poisonous animals in Iran and have always been noticed for their stings and being deadly. These arthropods are nocturnal and use their poison for hunting insects and defense [14].

Bees and wasps are among the most effective arthropods in the environment. The wasp of Vespidae family have social life. Two species of Vespa genus have been reported in Iran and Vespa orientalis or Cow wasp its local name Zar or Gunj is highly widespread [15-19]. Although many insects cause 
problems for human through stinging, but animals that more likely sting include honey bee, ordinary paper-making hornet wasps, yellow jacket and fire ants [20-23]. Fire ants of Pachycondyla sennaarensis species (Hymenoptera: Formicidae) living in Gheshm Island in Iran's territorial waters in Persian Gulf are considered one of the stinging ants [24,25]. Since social insects such as bees and wasps live socially, if they are threatened, they attack in group and it is possible that human be stung by a large number of them at the same time and this makes the problem more intense. Despite snake biting, in insects stinging only one point is visible or observable $[3,4,7]$. The intensity of bee sting is different in different individuals. Symptoms and the general signs of bee sting include sudden pain, redness, itching, swelling, change in skin color, breathing problem, unconsciousness, anaphylactic shock and damage to internal organs. About $10 \%$ of the individuals stung show redness and swelling in the site of the sting [26,27]. Wasp and bee poison causes damage to body and this damage are mostly limited to the areas near the site of the sting and sometimes leads to systemic effects that could be problematic.
Almost 40 to 100 cases of death caused by allergic reaction of insects stings occur annually in America and deadly allergic reactions mostly occur in individuals who have had the previous history of allergy a specific insect sting [28-32]. In non- allergic individuals to bee stings, although bee sting is painful, it does not cause any serious problem but in the same people also numerous or multiple stings cause intensive effects such as destruction of muscles and kidney failure and even in some cases death [33-37]. Wasps as urban pests cause many stings in human environment in the villages and cities. The presence and activity of wasps in open spaces like yards, parks and school campuses leads to distraction in ordinary activities and in case of invading homes, they can threaten children and the elderly. Thus, understanding various aspects of their biology and ecology can increase our knowledge about different behaviors of these animals and reduce the dangers caused by their activities. This study aimed to identify habitats and behavioral characteristics of hornet wasp (Vespa orientalis) in Kashan County, Central Iran.

Table 1. Comparison of observational parameters and the difference among four Vespa orientalis wasp nests.

\begin{tabular}{|c|c|c|c|c|}
\hline Characteristics & 1 & 2 & 3 & 4 \\
\hline $\begin{array}{l}\text { Environmental situation of the } \\
\text { nest }\end{array}$ & Faculty of Health & Ghotb Ravandi Township & Margin of Mazegan Village & Fin of Kashan \\
\hline Entrance location & In the hole beside window & In the hole of brick wall & Stone crack in rocky slopes & Hole in the ground \\
\hline Height from the ground & 10 meters above & 3 meters above & 15 meters above on the hillside & 30 centimeters above earth \\
\hline Tumulus & - & - & - & One way \\
\hline Size of tumulus grains & - & - & - & 3 to $12 \mathrm{~mm}$ \\
\hline Tumulus Texture & - & - & - & Dried clay \\
\hline Entrance size $(\mathrm{cm})$ & $3 \times 4$ & $3 \times 4$ & $3 \times 8$ & $4 \times 7$ \\
\hline Number of entries in 5 minutes & 15 & 12 & 18 & 20 \\
\hline $\begin{array}{l}\text { Number of departure outputs in } \\
5 \text { minutes }\end{array}$ & 19 & 15 & 13 & 17 \\
\hline $\begin{array}{l}\text { Time to prepare the defense the } \\
\text { nest in second }\end{array}$ & 50 & 45 & 60 & 40 \\
\hline $\begin{array}{l}\text { Tumulus distance from the nest } \\
\text { Entrance }\end{array}$ & - & - & - & $10 \mathrm{~cm}$ to $1 \mathrm{~m}$ \\
\hline Type of prey & $\begin{array}{l}\text { Cockroaches and garden and } \\
\text { home pest }\end{array}$ & $\begin{array}{l}\text { Cockroaches and garden and } \\
\text { home pest }\end{array}$ & $\begin{array}{l}\text { Larvae of Butterflies and Honey } \\
\text { bees }\end{array}$ & $\begin{array}{l}\text { Hemilepistus schirasi and } \\
\text { larvae of garden and crops } \\
\text { larvae }\end{array}$ \\
\hline
\end{tabular}

\section{Method and Materials}

Present study was of descriptive type. First, the living location of this wasp was identified in Fin-Bozorg, Ghotb-Ravandi Township and School of Public Health (in Kashan City) and margin of Mazgan Village (in Ghamsar City). During this study, four nests and the possible living location of Vespa orientalis were identified. Some of the wasp specimens were hunted and were preserved in 70\% ethanol and then were transferred to entomology laboratory in Department of Environmental Health in Kashan University of Medical
Sciences. The specimens were identified based on morphological studies using valid and specific keys as Vespa orientalis. Then, the exterior characteristics of the nests of this arthropod were recorded and also to measure the particles of the embankment (or tumulus), some of it was brought to the laboratory. Meanwhile, it was compared with the tumulus texture of its coexistence animal, that is, Hemilepistus schirasi Lincoln, 1970 (Crustacea: Isopoda). This study was conducted only on agricultural lands. In other nests, there was not tumulus or it was not observed. The nest of this animal was studied on the basis of density and frequency of active wasp and its 
important medical-health pest.

defense position in mountainous, residential and administrative habitats. The study was done during spring and summer from May to September during 2016-2017. Nest Data and the characteristics of the tumulus were recorded and were presented using figures and descriptive tables.

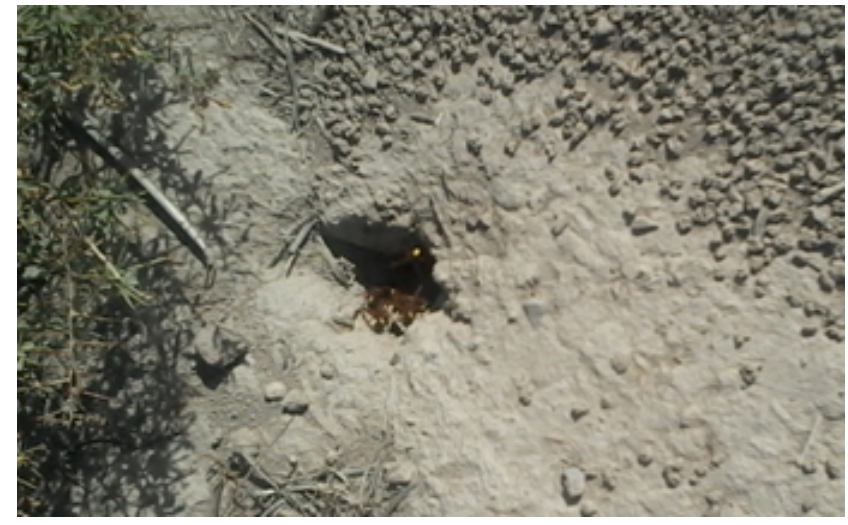

Figure 1. Aggregation of Vespa Orietalis wasps in the entrance of the nest for defense and attack.

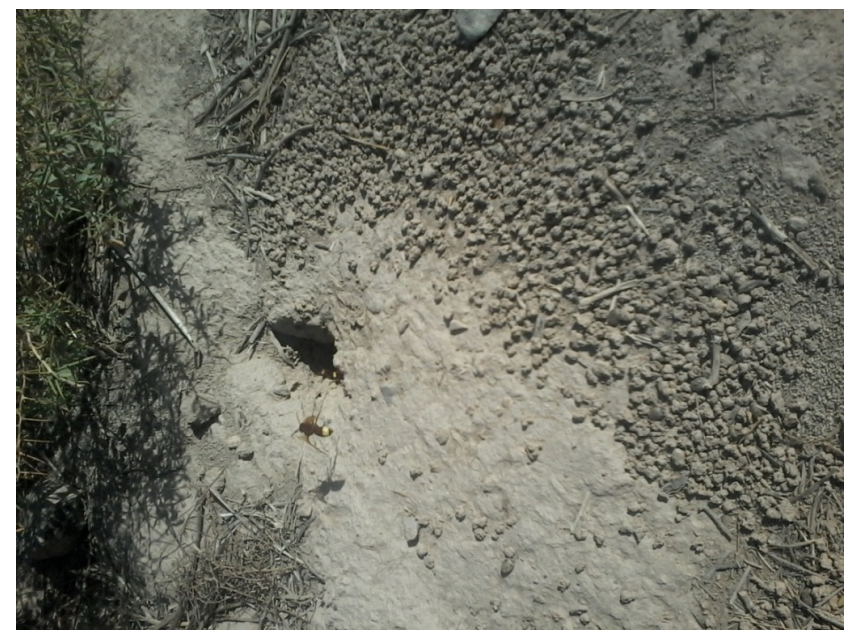

Figure 2. Tumulus dried particles and the entrance of Vespa Orientalis nest.

\section{Results}

The main sign indicating the existence of Vespa orientalis wasp's nest are the daily commute for the purpose of supplying food for colony and or in case of feeling danger from human or other creatures, flights denser than those of normal state and readiness to defend their nest and attack status. Defense prep time, in seconds, after seeing a man in a distance of about two meters varied from forty to sixty seconds. The shape and the entrance to the nest depend on the physical structure of the soil and the type of the habitat (Table 1 and Figure 1). If the nest is on the ground with soil texture, the existence of the embankment is due to cleaning it during the activity. The results revealed that the size of tumulus grains in the Vespa orientalis' nest in the farmland is due to cleaning the nest entrance tunnels after each rainfall or irrigation that has been transferred or moved out in the form of mud and with high humidity using oral aviary and has been poured at distance of
10-100 $\mathrm{cm}$ from the nest entrance (Figure 2). The physical structure of tumulus particles is very irregular and it was the clay particles logged out of the nest tunnel that have been dried in the air but their size varied from 3-10 $\mathrm{mm}$, the average size of the dried clay grains was around 7-8 $\mathrm{mm}$. The number of Tumulus was great and was estimated from 5000-7000 indicating that a large number of wasps had been active inside the nest (Figure 3). There was not tumulus in the nests inside the building walls and the cracks of mountainous regions. Vespa orientalis wasps are outstanding hunters that hunt wandering American cockroaches in the early days and after paralyzing the prey, they slice and carry them it into their nest. Hemilepistus schirasi, and the beetle and the butterflies larvae of gardens and surrounding farms were the most abundant nutrition in the farmland of Mazegan region (Figure 4).

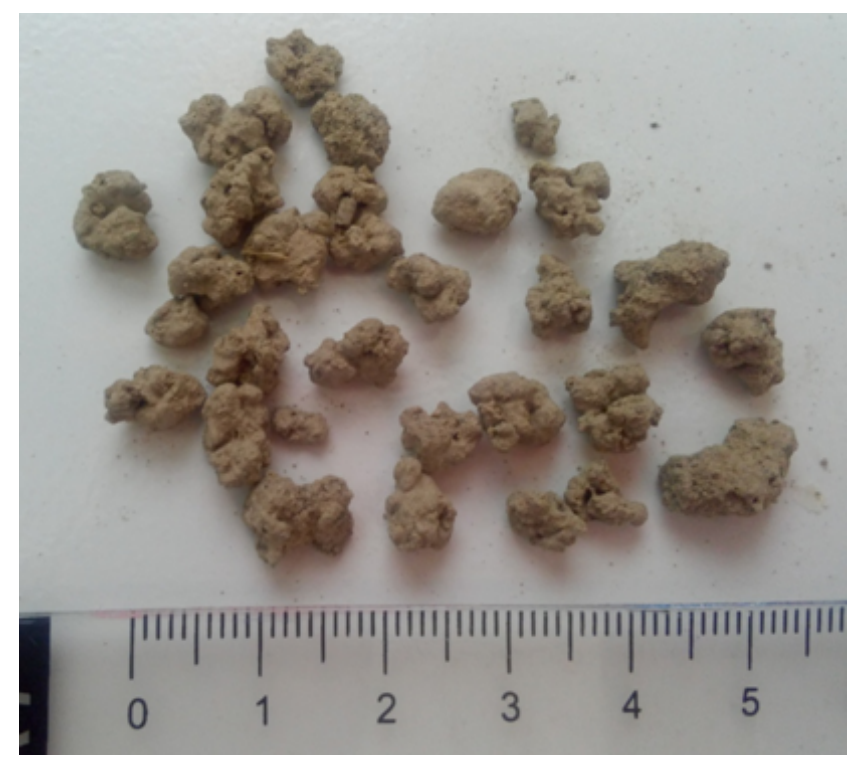

Figure 3. Tumulus dried grains and the entrance of Vespa Oriatalis nest.

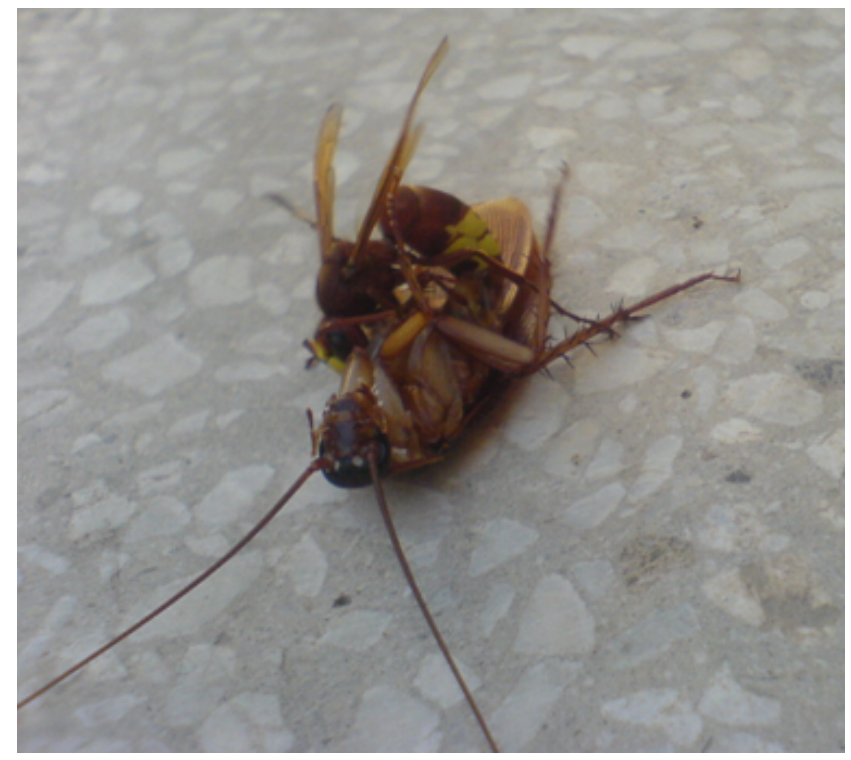

Figure 4. Vespa Orientalis while hunting American cockroach. 


\section{Discussion}

Study results showed that hornet wasps use different places to build their nest or paper honey comb. The place or location is usually selected that has enough space for building hive and is not accessible for their natural enemies; thus, it could be said that these animals are very opportunistic in terms of selecting the place of building their hive. They could be called the builders, occupiers or tenants of the nest. Around the newly cleaned entrance of the nest related to hornet wasps, the embankment or the one-way and very irregular tumulus is observed .Their nest entrance ranges from 3-8 cm on farmlands and their tumulus is different from that of other nest-builder animals [37-39]. The size of tumulus grains ranged from 3-12 $\mathrm{mm}$ that was estimated between 5000-7000 that indicated the activity of a large population of these wasps inside the nest. These paticles have higher density up to $1 \mathrm{~m}$ from the nest. Some of the researchers in their study have demonstrated the amount of soil from excavation is proportionate to the size of the nest-builder animal such as scorpions [40]. On the other hand, dried mud blocks from excavation are to some extent large and heavy and have been spread or dumped with distance from the entrance that are not easily removable. Therefore, the nest of this animal is less obstructed by the return of tumulus grains excavated that is consistent with the activity of other animals in this case [36,37].

The results showed that this animal as a predator selects its habitats in a way that it can provide its food or prey including the use of the honey bee during the growth season of the colony. The nest is usually selected for a long time. Some animals dig temporary holes whereas others build permanent nests [41-44]. Given the type of climate, the location of building wasp hive is selected in a way that it can protect their community especially their larvae from the damage and intensive or extreme climatic effects [45]. The results showed that tumulus is not always observed for selecting nest by these wasps but it is observable in locations where the entrance and the tunnel leading to the hive becomes narrow and limited as a result of water and wind erosion and in these conditions hornet wasps start to clean it. This means that most of the nests of this arthropod lack tumulus since they have been located at high locations or inside the large holes of the hive. In these cases, much like other animals as an opportunistic animal or arthropod, it uses the holes and cracks as its nest [36].

The study results showed that these animals alertly protect their nests and hives and after a very short time, they are ready as a group to attack and sting the threatening factors. This preparation is done using defense formula [46,47 ]. This has put it among the most dangerous and stinging animals that can attack in group and put especially the playful and curious children in serious risk. It seems that hornet wasps are opportunistic in terms of nest selection. In selecting the location for building nests, they consider following conditions: the wasps, their larvae and pupae must be protected from exhausting heat and dry climate and the nests must be close to the habitat of their diet animals and arthropods. It is suggested that all holes and cracks in the walls of residential and administrative building be filled or blocked with plaster, sand and cement. In case of existence of an active nest, try to displace it with complete protective full cover to an appropriate impervious location in the nature.

\section{Acknowledgement}

This study was conducted at the Social Determinants of Health Research Center and Department of Environmental Health, Kashan University of Medical Sciences, Kashan, Iran, in collaboration with the Department of Medical Entomology, School of Health, Ahvaz Jundishapur University of Medical Sciences, Ahvaz, Iran, and thanks to them. The study was approved by the Social Determinants of Health Research Center of Kashan University of Medical Sciences. The ethical principles of this research were investigated and discussed in the research committee of the above mentioned department and after making needed modifications, it was approved. The study has been done in accordance with the provisions of the Hillsinki Declaration.

\section{References}

1. Dehghani R, Kassiri H, Gharali B , Hoseindoost G, Chimehi E. Introducing of a new sting agent of velvet ant Dentilla sp. (Hymenoptera: Mutillidae) in Kashan, Centerl of Iran (2014 - 2015). Arch Clin Infect Dis 2018; 13: 60553.

2. Dehghani R, Sharif A, Madani M, Kashani HH, Sharif MR. Factors influencing animal bites in Iran: A Descriptive Study .Osong Public Health Res Perspect 2016; 7: 273-277.

3. Dehghani R, Rastegar Pouyani N, Dadpour B, Keyler D, Panjehshahi M, Jazayeri M, Omid Mehrpour, Habibi Tamijani A. A survey on non-venomous snakes in Kashan (Central Iran). J Biol Today's World 2016; 5: 65-75.

4. Dehghani R, Mehrpour O, Shahi MP, Jazayeri M, Karrari P, Keyler D, Zamani N. Epidemiology of venomous and semi-venomous snakebites (Ophidia: Viperidae, Colubridae) in the Kashan city of the Isfahan province in Central Iran. J Res Med Sci 2014; 19: 33-40.

5. Dehghani R, Reza Sharif MR, Moniri R, Sharif A, Haddad Kashani H. The identification of bacterial flora in oral cavity of snakes. Comp Clin Pathol 2016; 25: 279-283.

6. Dehghani R, Sharif A, Assadi MA, Haddad Kashani H, Sharif MR. Fungal flora in the mouth of venomous and non-venomous snakes. Comp Clin Pathol 2016; 25: 1207-1211.

7. Dehghani R, Fathi B, Shahi MP, Jazayeri M. Ten years of snakebites in Iran. Toxicon 2014; 90: 291-298.

8. Yousef-Mogaddam M, Dehghani R, Enayati AA, FazeliDinan M, Motevalli Haghi F. Epidemiology of scorpionism in Darmian, Iran, 2015. J Mazandaran Univ Med Sci 2016; 26: 131-136.

9. Yousef-Mogaddam M, Dehghani R, Enayati AA, FazeliDinan M, Vazirianzadeh B, Yazdani-Cherati J. Scorpion 
important medical-health pest.

fauna (Arachnida: Scorpiones) in Darmian County, Iran (2015-2016). J Mazandaran Univ Med Sci 2017; 26: 108-118.

10. Shahbazzadeh D, Amirkhani A, Djadid ND, Bigdeli S, Akbari A, Ahari H, Amini H, Dehghani R. Epidemiological and clinical survey of scorpionism in Khuzestan province, Iran (2003). Toxicon 2009; 53: 454-459.

11. Ghafourian M, Ganjalikhanhakemi N, Hemmati AA, Dehghani R, Kooti W. The Effect of Hemiscorpius lepturus (Scorpionida: Hemiscorpiidae) Venom on leukocytes and the leukocyte subgroups in peripheral blood of rat. J Arthropod-Borne Dis 2016; 10: 159-167.

12. Dehghani R, Miranzadeh MB, Yosefzadeh M, Zamani S. Fauna aquatic insects in sewage maturation ponds of Kashan university of medical science 2005. Pak J Biol Sci 2007; 10: 928-931.

13. Dehghani R, Zarghi I, Aboutalebi M, Barzegari Z, Ghanbari M. Fauna and habitat of aquatic arthropods of Kashan in 2010. Bangladesh J Med Sci 2014; 13: 306-310.

14. Dehghani R, Arani MG. Scorpion sting prevention and treatment in ancient Iran. J Tradit Complement Med 2015; 5: 75-80.

15. Ebrahimi E, Carpenter JM. Distribution pattern of the hornets Vespa orientalis and V. crabro in Iran: (Hymenoptera: Vespidae). Zoology Middle East 2012; 56: 63-66.

16. Abbasi R, Rad SP, Ebrahimi E, Sheidaei M. Faunistic study of vespid wasps in Zanjan Province (Northwest of Iran) with some ecological measures. Environ Sci 2008; 6: 65-74.

17. Abbasi R. On the distribution and taxonomy of vespine wasps of Iran (Hymenoptera: Vespidae: Vespinae). Acta Musei Moraviae, Scientiae biologicae (Brno) 2012; 97: 69-86.

18. Rad SP, Abbasi R, Soleimani G, Dvorák L. New and supplementary information on the vespid fauna of Iran: (Hymenoptera: Vespidae). Zoology Middle East 2010; 50: 95-100.

19. Bagriaçik N, Samin N. A checklist of Iranian Vespinae (Hymenoptera: Vespoidea: Vespidae). Arch Biol Sci 2011; 63: 487-492.

20. Khoobdel M, Tavassoli M, Salari M, Firozi F. The stinging Apidae and Vespidae (Hymenoptera: Apocrita) in Iranian islands, Qeshm, Abu-Musa, Great Tunb and Lesser Tunb on the Persian Gulf. Asian Pacific J Tropical Biomed 2014; 4: S258-S262.

21. Diaz JH. Recognition, management, and prevention of hymenopteran stings and allergic reactions in travelers. J Travel Med 2009; 16: 357-364.

22. Viswanathan S, Prabhu C, Arulneyam J, Remalayam B, Adil M. Yellow jacket envenomation-related acute renal failure. NDT Plus 2011; 4: 167-169.
23. Zhang L, Yang Y, Tang Y, Zhao Y, Cao Y, Su B, Fu P. Recovery from AKI following multiple wasp stings: A case series. Clin J Am Soc Nephrol 2013; 8: 1850-1856.

24. Khoobdel M, Akbarzadeh K, Jafari H, Mehrabi Tavana A, Mousavi Jazayari A, Rafienejad J, Iizadi M, AA AE, Jahani Y, Nobakht M, Bahmani MM. Ant sting in military forces on three Persian islands of Abu-Musa, Great Tonb and Lesser Tonb. J Mil Med 2012; 14: 155-162.

25. Rafinejad J, Zareii A, Akbarzadeh K, Azad M, Biglaryan F, Doosti S, Sedaghat MM. Faunestic study of ants with emphasis on the health risk of stinging ants in Qeshm Island, Iran. Iranian J Arthropod-Borne Dis 2009; 3: 53-59.

26. Severino M, Bonadonna P, Passalacqua G. Large local reactions from stinging insects: from epidemiology to management. Curr Opin Allergy Clin Immunol 2009; 9: 334-337.

27. Golden DB, Moffitt J, Nicklas RA, Freeman T, Graft DF, Reisman RE, Tracy JM, Bernstein D, Blessing-Moore J, Cox L, Khan DA, Lang DM, Oppenheimer J, Portnoy JM, Randolph C, Schuller DE, Spector SL, Tilles SA, Wallace D; Joint Task Force on Practice Parameters; American Academy of Allergy, Asthma \& Immunology (AAAAI); American College of Allergy, Asthma \& Immunology (ACAAI); Joint Council of Allergy, Asthma and Immunology. Stinging insect hypersensitivity: a practice parameter update 2011. J Allergy Clin Immunol 2011; 127: 852-854.

28. Bilo BM, Bonifazi F. Epidemiology of insect-venom anaphylaxis. Curr Opin Allergy Clin Immunol 2008; 8: 330-337.

29. Valentine MD, Schuberth KC, Kagey-Sobotka A, Graft DF, Kwiterovich KA, Szklo M, Lichtenstein LM. The value of immunotherapy with venom in children with allergy to insect stings. $\mathrm{N}$ Engl J Med 1990; 323: 1601-1603.

30. Lin $\mathrm{CJ}, \mathrm{Wu} \mathrm{CJ}$, Chen $\mathrm{HH}$, Lin HC. Multiorgan failure following mass wasp stings. South Med J 2011; 104: 378-379.

31. Turbyville JC, Dunford JC, Nelson MR. Hymenoptera of Afghanistan and the central command area of operations: assessing the threat to deployed US service members with insect venom hypersensitivity. Allergy Asthma Proceed 2013; 34: 179-184.

32. Pumphrey RS. Lessons for management of anaphylaxis from a study of fatal reactions. Clin Exp Allergy 2000; 30: 1144-1150.

33. Radhakrishnan $H$. Acute kidney injury and rhabdomyolysis due to multiple wasp stings. Indian J Crit Care Med 2014; 18: 470-472.

34. Rachaiah NM, Jayappagowda LA, Siddabyrappa HB, Bharath VK. Unusual case of acute renal failure following multiple wasp stings. N Am J Med Sci 2012; 4: 104-106.

35. Yang L. Acute Kidney Injury in Asia. Kidney Dis (Basel) 2016; 2: 95-102. 
36. Dehghani R. Kamiabi F. Frequency of Odonthubutus doriae Thorell 1876 nests in desert soils, Esfahan, Iran. J Ent Res 2017; 41: 13-18.

37. Kashani GM, Sari A, Hosseinie SH. Terrestrial isopods of the subgenus Hemilepistus (Hemilepistus) Budde-Lund, 1879 (Isopoda: Oniscidea) from Iran. Zootaxa 2010; 2549: 54-68.

38. Hermes MG, Araujo G, Antonini Y. On the nesting biology of eumenine wasps yet again: Minixi brasilianum (de Saussure) is a builder and a renter at the same time! (Hymenoptera, Vespidae, Eumeninae). Revista Brasileira de Entomologia 2015; 59: 141-142.

39. Williams SC. Scorpion bionomics. Annu Rev Entomol 1987; 32: 275-295.

40. Rutin J. The burrowing activity of scorpions (Scorpio maurus palmatus) and their potential contribution to the erosion of Hamra soils in Karkur, central Israel. Geomorphology 1996; 15: 159-168.

41. Perrard A, Haxaire J, Rortais A, Villemant C. Observations on the colony activity of the Asian hornet Vespa velutina Lepeletier 1836 (Hymenoptera: Vespidae: Vespinae) in France. Annales de la Société Entomologique de France 2009; 45: 119-127.

42. Dehghani R, Khamehchian T, Miranzadeh MB. Surveying on the biologic behaviors of Hemiscorpius lepturus (Peters, 1861) scorpion in laboratory (Khuzestan, Iran) (Scorpions: Hemiscorpiidae). Pakistan J Biol Sci 2007; 10: 3097-3102.

43. Nakamura M, Sonthichai S. Nesting habits of some hornet species (Hymenoptera, Vespidae) in Northern Thailand. Kasetsart J Nat Sci 2004; 38: 196-206.
44. Dehghani R, Valizade R, Mahmoodi S. A review of the scorpion predators and the introduction of Scarites subterraneus, as a new predatory of them in Iran . J Ent Res 2016, 40: 291-296.

45. Gefen E. Temperature dependence of water loss rates in scorpions and its effect on the distribution of Buthotus judaicus (Buthidae) in Israel. Compar Biochem Physiol 2006; 144: 58-62.

46. Cheng YN, Wen P, Dong SH, Tan K, Nieh JC. Poison and alarm: the Asian hornet Vespa velutina uses sting venom volatiles as an alarm pheromone. J Exp Biol 2017; 220: 645-651.

47. Buys S. Notes on the nesting behavior of the bee-hunting wasp Trachypus fulvipennis (Tachenberg, 1875) (Hymenoptera: Crabronidae). Boletim do Museu de Biologia Mello Leitão 2016; 38: 133-138.

\section{*Correspondence to}

Hamid Kassiri

Department of Medical Entomology

School of Health

Ahvaz Jundishapur University of Medical Sciences

Iran

Email: Hamid.Kassiri@yahoo.com 